\title{
PERAN KEPALA SEKOLAH DALAM PELAKSANAAN MANAJEMEN PEMASARAN SEKOLAH DASAR DI JEMBER JAWA TIMUR
}

\author{
Fathorrozi \\ Madrasah Tsanawiyah Nurul Qarnain Jember \\ fatnarozi@gmail.com \\ Abd. Muhith \\ UIN Kiai Haji Achmad Siddiq Jember \\ abd.muhith1972@gmail.com
}

DOI: $10.35719 /$ jieman.v3i2.73

\begin{abstract}
Abstrak
Penelitian ini bertujuan untuk mendeskripsikan tugas kepala sekolah sebagai manager dan leader pemasaran di sebuah Sekolah Dasar di Jember, Jawa Timur. Penelitian ini menggunakan pendekatan kualitatif. Teknik pengumpulan data yang digunakan adalah observasi partisipan pasif, wawancara semi terstruktur, dan dokumentasi. Hasil penelitian ini mengungkap dua hal. Pertama, tugas kepala sekolah sebagai manajer pemasaran di SD adalah dengan melakukan perencanaan yang meliputi identifikasi pasar dan target pasar; pengorganisasian dengan pembagian tugas sesuai kesepakatan; pelaksanaan yang meliputi pemasaran secara langsung, yaitu penyebaran brosur, pemasangan baliho, presentasi ke lembaga dan mengunjungi tokoh berpengaruh, dan pemasaran tidak langsung, yaitu khatmil Qur'an keliling, drumband, pemuatan foto kegiatan di kelas dan luar kelas, penyelenggaraan event lomba pada Peringatan Hari Besar Islam, program unggulan dan prestasi siswa; dan pengawasan dengan evaluasi capaian, menunjukkan hasil yang dicapai sesuai keinginan. Kedua, tugas kepala sekolah sebagai leader pemasaran di SD adalah dengan menerapkan strategi bauran pemasaran, ${ }_{4} \mathrm{P}$ yaitu, produk: program tahfidz
\end{abstract}


JIEMAN: Journal of Islamic Educational Management

juz 30 dan pengamalan pendidikan agama; harga: gratis tanpa biaya; tempat: sejuk, asri, terhindar dari keramaian dan menawarkan keberkahan; promosi: pembagian zakat dengan melibatkan siswa, berkunjung ke tokoh berpengaruh, dan khatmil Qur'an secara keliling.

Kata Kunci: peran kepala sekolah, manajemen pemasaran, bauran pemasaran, sekolah dasar

\begin{abstract}
This study aims to describe the principal duties as the marketing manager and leader marketing in the private Islamic primary school in Jember, East Java. This research uses qualitative approach. The data collection technique used in this research is passive participant observation, semistructured interview and documentation. This research finds two things. First, the principal duties as the marketing manager in the primary school are doing the planning that includes market segmentation, market target and program determination; organizing by dividing the tasks according to the agreed schedule; implementing direct and indirect marketing; and monitoring with provide direction, motivation and awareness to teachers on duty. Second, the principal duties as marketing leader in the primary school are applying marketing mixed strategy, 4 Ps. The Product: juz 30 tahfidz's program and practicing religious education; The Price: it's free; The Place: cool and fresh, beautiful, no crowd, and offers blessings; and The Promotion: distributing zakat with the students, visiting public figures, and doing door to door AlQuran recitation.
\end{abstract}

Keywords: role of principal, marketing management, marketing mix, elementary school

\title{
Pendahuluan
}

Kepala sekolah adalah salah satu komponen pendidikan yang paling berperan dalam meningkatkan kualitas pendidikan. ${ }^{1}$ Dengan ini berarti bahwa visi dan misi, serta strategi pemasaran harus dimiliki oleh kepala sekolah. Sebab strategi ini menjadi usaha sistematis untuk senantiasa memperbaiki kualitas layanan, sehingga

${ }^{1}$ E. Mulyasa, Menjadi Kepala Sekolah Profesional, (Bandung: PT Remaja Rosdakarya, 2018), 24. 
peserta didik, orang tua peserta didik, pemakai lulusan, guru, karyawan, pemerintah serta masyarakat akan merasa puas.

Kepala sekolah harus mampu mewujudkan pendidikan yang efektif dan efesien dengan cara membina dan mengembangkan hubungan kerja yang harmonis antara sekolah dengan masyarakat. Hubungan yang harmonis ini akan membentuk: (1) saling pengertian antara sekolah, orang tua, masyarakat dan lembaga-lembaga lain yang ada di masyarakat, termasuk dunia kerja; (2) saling membantu antara sekolah dan masyarakat karena mengetahui manfaat, arti dan pentingnya peranan masing-masing; (3) kerja sama yang erat antara sekolah dengan berbagai pihak yang ada di masyarakat dan mereka merasa ikut bertanggung jawab atas suksesnya pendidikan di sekolah. $^{2}$

Hal tersebut sesuai dengan tugas pokok dan fungsi kepala sekolah sebagaimana dirumuskan dalam Peraturan Menteri Pendidikan dan Kebudayaan Republik Indonesia pasal 15 nomor 6 tahun 2018 tentang penugasan guru sebagai kepala sekolah, yaitu beban kerja kepala sekolah sepenuhnya untuk melaksanakan tugas pokok manajerial, pengembangan kewirausahaan, dan supervisi kepada guru dan tenaga kependidikan. ${ }^{3}$

Berkenaan dengan tanggung jawab kepala sekolah sebagai pemimpin ini, Allah Azza wa Jalla menegaskan dalam surah alBaqarah ayat 30:

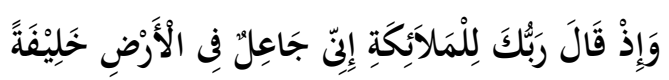

"Dan (ingatlah) ketika Tuhanmu berfirman kepada para malaikat, 'Aku hendak menjadikan khalifah di bumi."'

Berdasarkan ayat di atas dapat diketahui bahwa manusia memiliki tugas sebagai khalifah (pemimpin) di muka bumi. Tugas kepemimpinan ini tidak hanya ditujukan kepada Nabi Adam saja, melainkan juga untuk manusia pada umumnya. Tugas manusia

${ }^{2}$ E. Mulyasa, Menjadi Kepala Sekolah Profesional, 187.

${ }_{3}^{3}$ Peraturan Menteri Pendidikan dan Kebudayaan Nomor 6 Tahun 2018 Tentang Penugasan Guru sebagai Kepala Sekolah.

${ }^{4}$ QS. al-Baqarah: 30. 
adalah mengelola bumi dengan sebaik-baiknya dari segala aspek kehidupan, termasuk aspek pendidikan.

Oleh karena itu, pihak sekolah perlu membuat strategi dan inovasi atau gebrakan baru dalam pelaksanaan pemasaran. David A. Aaker mengatakan setidaknya perlu untuk mengembangkan kompetensi di sekitar lima tugas manajemen: 1) analisis strategis; 2) inovasi; 3) mengendalikan lebih dari satu unit bisnis; 4) mengembangkan keunggulan/keuntungan yang berkelanjutan; 5) mengembangkan dasar pertumbuhan. ${ }^{5}$

Tujuan dibuatnya strategi pemasaran sekolah adalah untuk menciptakan dan mempertahankan pelanggan dalam hal ini peserta didik dan orang tua peserta didik atau masyarakat. Proses perencanaan yang dilakukan yaitu analisis hasil prestasi kegiatan pemasaran dalam rapat akhir tahun yang selalu dilaksanakan tiap tahunnya. ${ }^{6}$ Produk yang ditawarkan kepada pelanggan merupakan produk yang secara global dapat direalisasikan dalam visi sekolah, yakni menjadi kualitas output yang rahmatan li al-alamiin. ${ }^{7}$ Strategi pemasaran pendidikan yang efektif adalah dengan menunjukkan bukti kualitas lulusan dan membangun citra kepuasan layanan melalui berita dari mulut ke mulut. ${ }^{8}$ Promosi yang dilakukan adalah dengan membuat spanduk yang dipasang di tempat yang strategis, menyebarkan brosur ke TK-TK, lewat media Facebook, Instagram

5 David Aaker A, Christine Moorman, Strategic Market Management, (Incorporated: John Wiley \& Sons, 2018), 2.

6 Baba Mukmin, "Manajemen Pemasaran Jasa Sekolah Dasar Terpadu." Jurnal Isema: Islamic Education Manajemen 5 (2020): 97-112. DOI: http:// dx.doi.org/10.15575/isema.v5i1.6o76

${ }^{7}$ Afidatun Hasanah, "Pendidikan Sebagai Strategi Peningkatan Mutu di SD Alam Baturraden.” Jurnal eL-Tarbawi 8 (2015): 161. DOI: http://dx.doi.org/10.20885/tarbawi.vol8.iss2.art4

8 Aditia Fradito, "Strategi Pemasaran Pendidikan dalam Meningkatkan Citra Sekolah.” Al-Idarah: Jurnal Kependidikan Islam Volume 10 (2020): 12. DOI: https://doi.org/10.24042/alidarah.v10i1.6203 
dan WhatsApp, serta melakukan hubungan dengan masyarakat melalui sosialisasi. ${ }^{9}$

Dengan semakin meluasnya lembaga pendidikan yang beraneka kelebihan, serta hadirnya lembaga pendidikan swasta yang menawarkan beragam fasilitas, hingga dengan biaya bersaing makin menambah maraknya daya saing pendidikan, maka strategi pemasaran jasa pendidikan penting dilaksanakan oleh kepala sekolah demi meningkatkan kualitas serta minat masyarakat terhadap lembaga. Sekolah Dasar NQ (SD NQ) yang berlokasi di Sukowono, Jember, Jawa Timur, ${ }^{1}$ terlihat menonjol meskipun terletak berdekatan dengan sekolah lain, sekolah swasta yang mampu menarik perhatian masyarakat, sehingga dari tahun ke tahun mempunyai peningkatan jumlah siswa ini, sangat menarik untuk diteliti terkait peran kepala sekolah sebagai manajer dan leader dalam pelaksanaan pemasaran.

\section{Pembahasan}

\section{Tugas Kepala Sekolah Sebagai Manajer dalam Pemasaran di Sekolah Dasar NQ Jember}

Dalam pemasaran di SD NQ Jember, kepala sekolah sebagai manajer telah melakukan tugas sebagai berikut:

1. Planning (Perencanaan)

Sebelum melakukan perencanaan pemasaran, Kepala SD NQ lebih dulu menata pendidik dan kependidikan, meliputi penyamaan niat dan visi serta linieritas kelulusan, kemudian menata program sebagai tujuan pendidikan. Kepala sekolah kemudian mengadakan musyawarah bersama dewan guru untuk menentukan langkah dan menentukan objek yang akan menjadi sasaran.

9 Aat Lisnawati, "Strategi Pemasaran Lembaga Pendidikan di Sekolah Dasar Dharma Mulia Dusun Banaran Getasan.” Jurnal Ilmiah Ekonomi dan Bisnis Vol. 17 (2020): 198-205. DOI: https://doi.org/10.31849/jieb.v17i2.4422

1 Sekolah Dasar NQ adalah sebuah sekolah dasar yang berada di bawah naungan Pondok Pesantren NQ yang berlokasi di Sukonowo, Jember, Jawa Timur. Pondok pesantren ini memiliki lembaga pendidikan mulai dari pra sekolah hingga perguruan tinggi. 
Sebagai langkah awal perencanaan pemasaran yang dilakukan oleh kepala sekolah adalah mengidentifikasi pasar. Identifikasi pasar ini dimaksudkan untuk mengetahui berbagai macam kebutuhan mayoritas calon murid atau wali murid dalam kaitannya dengan dunia pendidikan. SD NQ menyadari bahwa masyarakat butuh lembaga pendidikan berbasis keagamaan yang di dalamnya tak hanya membahas teori tetapi juga pengamalan. Langkah kedua adalah target pasar. Yang menjadi target pasar dalam kegiatan pemasaran SD NQ adalah wali murid PAUD dan TK/RA yang ada di Kecamatan Sukowono.

Hal ini diperkuat oleh Philip Kotler dan Gary Armstrong yang memaparkan, "Market segmentation involves dividing a market into distinct groups of buyers who have different needs, characteristics, or behaviors and who might require separate marketing strategies of mixes."

Mengenai segmentasi pasar, Lupiyoadi dan Hamdani dalam David Wijaya, mengemukakan bahwa segmentasi pasar merupakan membagi pasar menjadi kelompok pembeli yang dibedakan menurut tingkah laku, kebutuhan, atau karakteristik yang mungkin membutuhkan produk yang berbeda. ${ }^{1}$

Setelah menghubungkan antara hasil temuan penelitian dengan teori Philip Kotler, Gary Armstrong dan David Wijaya dapat disimpulkan bahwa segmentasi pasar yang menjadi langkah awal merencanakan kegiatan pemasaran SD NQ sudah sesuai dengan proses perencanaan strategis, sebab dengan membagi penggunaan jasa menjadi beberapa segmen akan memberikan gambaran bagi lembaga untuk menetapkan segmen mana yang akan dilayani.

2. Organizing (Pengorganisasian)

Pengorganisasian dalam pemasaran SD NQ Sukowono Jember adalah pembagian tugas. Tugas-tugas dalam memasarkan lembaga telah dibagi dengan baik dan sempurna oleh kepala sekolah. Waktu

1 Philip Kotler and Gary Armstrong, Principles of Marketing, (Prentice Hall International: Pearson, 2019), 212.

1 David Wijaya, Pemasaran Jasa Pendidikan, (Jakarta: Bumi Aksara, 2016), 47 . 
dan tempat memasarkan SD NQ untuk masing-masing guru tidaklah sama. Semua telah diatur oleh kepala sekolah dengan kesepakatan bersama. Bahkan kepala sekolah pun juga kebagian tugas untuk mengunjungi tokoh berpengaruh dan wali murid alumni SD NQ.

Temuan di atas selasar dengan teori George R. Terry yang menyatakan bahwa organizing mencakup: (1) membagi komponenkomponen kegiatan yang dibutuhkan untuk mencapai tujuan ke dalam kelompok-kelompok, (2) membagi tugas kepada seorang manajer untuk mengadakan pengelompokan tersebut, dan (3) menetapkan wewenang di antara kelompok atau unit-unit organisasi. $^{1}$

Sofjan Assauri memperkuat teori di atas dengan pernyataannya bahwa usaha pelaksanaan kegiatan pemasaran tidak mungkin hanya dilakukan sendiri oleh satu orang. Oleh karena itu, usaha pelaksanaan kegiatan pemasaran dilakukan oleh sekelompok orang harus diorganisasi dan dikoordinasi sehingga dapat diharapkan tercapainya tujuan dan sasaran dalam bidang pemasaran. ${ }^{1}$

3. Actuating (Pelaksanaan)

Strategi pemasaran lembaga yang telah dilakukan oleh Kepala SD NQ, terbagi menjadi dua macam, yaitu secara langsung dan tidak langsung.

a. Pemasaran secara langsung, antara lain melalui:

1) Penyebaran brosur yang memuat visi-misi dan program unggulan yang dikemas dengan tulisan dan gambar menarik. Penyebaran brosur via media online dinilai lebih efektif.

2) Pemasangan baliho dan spanduk, berfungsi menginformasikan jasa yang ditawarkan dan pemuatan program unggulan agar mampu menarik minat calon peserta didik.

3) Presentasi ke lembaga-lembaga sekitar, setelah disepakati hari dan tempat untuk presentasi, para guru yang ditugasi kepala

1 George R. Terry, Prinsip-Prinsip Manajemen, terj. J. Smith. D.F.M., (Jakarta: Bumi Aksara, 2018), 16.

1 Sofjan Assauri, Manajemen Pemasaran, (Jakârta: Rajawali Pers, 2018), 323. 
sekolah kemudian bergerak menuju lembaga pendidikan yang disasar.

4) Mengunjungi tokoh berpengaruh, kepala sekolah terjun ke berbagai tokoh masyarakat dan perangkat desa, seperti kepala desa, kaur, staf desa, ketua RT, ketua RW dan bidan.

b. Pemasaran secara tidak langsung, antara lain melalui:

a) Khatmil Qur'an keliling, diadakan secara bergiliran ke daerah masing-masing siswa kelas 4, 5 dan 6. Saat khatmil Qur'an, siswa yang mengaji dibantu dengan memakai alat pengeras suara di masjid sehingga suara mereka terdengar ke manamana.

b) Seni drumband, merupakan wujud implementasi dari masukan dan permohonan sebagian wali murid.

c) Pemuatan foto kegiatan siswa ke media sosial, foto-foto kegiatan siswa baik yang di dalam kelas maupun di luar kelas telah dapat dijumpai di berbagai media sosial, terutama di media sosial milik SD NQ. Kegiatan siswa di luar kelas, seperti study banding ke Milku Mangli dan Rumah Sakit Bina Sehat Jember.

d) Penyelenggaraan event lomba pada hari besar Islam yang diikuti oleh siswa TK/RA sekecamatan Sukowono, sebelum acara lomba dimulai, biasanya ada penampilan pentas seni yang diisi oleh siswa SD sebagai bahan pengenalan bahwa di daerah Baletbaru terdapat SD yang berbasis islami.

e) Program unggulan, berupa Tahfidz al-Qur'an serta program pendidikan agama Islam dan penerapannya. Program ini diyakini oleh pihak sekolah sebagai program yang sangat diminati para orang tua calon siswa untuk memberi pemahaman dan menanamkan ilmu agama sejak kecil.

f) Prestasi siswa, sebagai imbalan tambahan dari sekolah, juara lomba yang bersangkutan diberi hadiah oleh pihak sekolah dan diabadikan menggunakan baliho yang kemudian dipajang di depan pintu gerbang. 
Hasil temuan peneliti tersebut senada dengan pendapat Hill dan Jones ${ }^{1}$ yang mengatakan bahwa agar dápat menghadapi tantangan tersebut (persaingan), pemimpin sekolah selaku pemimpin pendidikan seharusnya mengembangkan keunggulan kompetitif (competitive advantage) sekolah yang tidak mudah ditiru sekolah kompetitor. Keunggulan kompetitif sekolah dapat diciptakan melalui strategi efisiensi, kualitas produk, dan inovasi.

Mengenai seni drumband, Buchari Alma berpendapat bahwa kegiatan drumband dan tim kesenian dari suatu sekolah yang menampilkan kebolehannya pada suatu acara resmi akan memperoleh keuntungan promosi yang luar biasa. Sekolah yang memiliki manajemen baik akan mengarahkan perhatiannya lebih membina kegiatan bidang ini, karena ini membuka peluang bagi sekolah untuk lebih dikenal oleh masyarakat dan pemerintah. ${ }^{1}$

Dari dialog antara hasil temuan dengan teori Buchari Alma di atas menunjukkan bahwasanya temuan penelitian dalam pelaksanaan pemasaran SD NQ yang dilakukan oleh kepala sekolah, baik secara langsung ataupun tidak langsung, menguatkan konsep competitive advantage menurut Hill dan Jones.

4. Controlling (Pengawasan)

Salah satu bentuk pengawasan kepala sekolah atas pelaksanaan pemasaran SD NQ adalah memberi arahan, dorongan kepada guru yang bertugas. Juga memberi penyadaran kepada bawahan bahwa lembaga pendidikan ini adalah ladang amal. Jadi kesempatan emas untuk menimbun dan menabung amal kebaikan. Kepala sekolah juga memberi penyadaran bahwa buat apa sekolah jika hanya ada guru dan sarana prasarana, tetapi siswanya tidak ada.

Pengawasan atau evaluasi yang dilakukan oleh kepala sekolah terhadap pelaksanaan pemasaran SD NQ telah berjalan baik. Apa yang direncanakan telah membuahkan hasil dan mencapai maksimal. Salah satu buktinya dapat ditunjukkan ketika pembukaan

1 David Wijaya, Pemasaran Jasa Pendidikan, $81^{5}$

1 Buchari Alma, Manajemen Pemasaran E Pémasaran Jasa, (Bandung: Alfabeta 2018), 385 . 
pendaftaran siswa baru, yang mendaftar sampai memenuhi kouta, bahkan lebih.

Hasil temuan penelitian di atas sesuai dengan teori Sofjan Assauri dengan menyatakan bahwa manajer pemasaran yang berhasil adalah manajer yang mampu mengevaluasi, apakah keputusan yang diambilnya dapat membantu dan berhasil mencapai tujuan perusahaan. Seperti diketahui, tujuan perusahaan adalah untuk menjamin kelangsungan hidup usaha perusahaan, untuk dapat berkembang dan untuk mampu bersaing. ${ }^{1}$

Ayu Sri Menda Br Sipetu mengatakan bahwa kemampuan mengawasi atau menilai (evaluation) merupakan kemampuan untuk membuat penilaian sendiri dan menentukan apakah suatu pertanyaan benar atau suatu tindakan dianggap bijaksana atau tidak, serta tidak hanya mencetuskan gagasan saja tapi juga melaksanakannya. ${ }^{1}$

Cucun Sunaeningsih juga berpendapat bahwa evaluasi dari tahun sebelumnya menjadi acuan untuk menetapkan perencanaan baru untuk tahun berikutnya atau mempertahankan perencanaan lama yang sudah ada. ${ }^{1}$

Setelah mendialogkan antara hasil temuan penelitian dengan konsep yang ada, dapat disimpulkan bahwa pengawasan atau evaluasi yang dilakukan oleh kepala sekolah dalam kegiatan pemasaran SD NQ memperkuat dan mengembangkan teori Sofjan Assauri, Ayu Sri Menda Br Sipetu dan Cucun Sunaeningsih.

\section{Tugas Kepala Sekolah Sebagai Leader dalam Pemasaran di Sekolah Dasar NQ Jember}

Sebagai pemimpin di sekolah, kepala sekolah harus mampu menggerakkan seluruh sumber daya manusia untuk dapat bekerja secara maksimal. Dalam melaksanakan tugas sebagai leader, Kepala

1 Sofjan Assauri, Manajemen Pemasaran, 362.

1 Ayu Sri Menda Br Sipetu, Pengembangan Kreativitas Siswa, (Bogor: Guepedia, 2019), 25.

Cucun Sunaeningsih, Pengelolaan Pendidikan, (Sumedang: UPI Sumedang Press, 2017), 99. 
SD NQ menerapkan bauran pemasaran untuk mengatur strategi promosi lembaga. Cara untuk mencapai dan mempertahan-kan keunggulan kompetitif adalah melalui pemanfaatan unsur-unsur bauran pemasaran. Konsep bauran pemasaran pertama kali diutarakan oleh Jerome McCarthy yang mengemukakan empat unsur utama bauran pemasaran yang dikenal dengan istilah “4P”, yaitu product (produk), price (harga), place (tempat), dan promotion (promosi). ${ }^{2}$

\section{Product (Produk)}

Product atau produk dalam dunia pendidikan maksudnya adalah program pendidikan yang ditawarkan kepada pengguna jasa untuk memenuhi keinginan atau kebutuhan mereka. Banyak wali murid yang merasa puas dengan program ekstra yang telah dibuat oleh SD NQ yang tentunya atas arahan dan persetujuan kepala sekolah. Putra-putri mereka menjadi baik dan lancar dalam membaca al-Qur'an, bahkan bisa hafal Juz Amma. Lulusan SD NQ banyak tersebar ke pondok pesantren besar di Jawa Timur, seperti di Gontor, Nurul Jadid (masuk program tahfidz dengan menguasai 2 juz), Al-Islah Bondowoso (masuk program tahfidz), Nurul Islam Antirogo (masuk program tahfidz), Wali Songo Situbondo (masuk program tahfidz), serta ada pula yang masuk SMP Negeri dan MTsN 6 Jember (masuk di kelas unggulan).

Produk yang mampu memuaskan pelanggan ini butuh persiapan yang matang sebagaimana Christopher Lovelock menyampaikan bahwa jika sebuah produk didesain dengan buruk, maka tidak akan menciptakan nilai yang berarti bagi para pelanggan. Merencanakan bauran pemasaran dimulai dengan menciptakan konsep jasa yang akan memberikan nilai kepada pelanggan yang dituju dan memuaskan kebutuhan mereka lebih baik daripada alternatif dari pesaing lain. ${ }^{2}$

Fandy Tjiptono memperkuat pernyataan di atas dengan menyatakan bahwa kepuasan pelanggan merupakan indikator

2 David Wijaya, Pemasaran Jasa Pendidikan, $68^{0}$.

2 Jochen Wirtz, Christopher Lovelock, Services Marketing: People, Technology, Strategy, Eight Edition, (USA: World Scientific, 2016), 69. 
kesuksesan bisnis di masa depan yang mengukur kecenderungan reaksi pelanggan terhadap perusahaan di masa yang akan datang. ${ }^{2}$

Berdasarkan hasil temuan dan teori di atas menunjukkan bahwasanya program tahfidz al-Qur'an, qira'atul Qur'an serta pembiasaan amaliah keagamaan yang menjadi produk / program unggulan SD NQ telah mampu memuaskan pelanggan sebagai cikal bakal kesuksesan sekolah secara berkelanjutan, temuan ini sesuai dengan teori Christopher Lovelock dan Fandy Tjiptono.

2. Price (Harga)

Price atau harga merupakan sejumlah uang sebagai alat tukar untuk memperoleh produk atau jasa yang harus diberikan konsumen kepada produsen. Harga dalam konteks jasa pendidikan adalah seluruh biaya yang dikeluarkan oleh siswa untuk mendapatkan jasa pendidikan yang ditawarkan oleh sekolah. ${ }^{2}$ Sementara itu, SD NQ tidak memungut biaya apapaun alias gratis. Benar-benar tidak ada pemungutan uang sama sekali, baik uang SPP, iuran gedung, perawatan sarana prasarana atau pun lainnya. Hal ini berasal dari inisiatif pengasuh ingin mendidik putra-putri warga sekitar yang kurang mampu dalam pembiayaan.

Dari awal pendirian SD NQ, niat pengasuh memang khusus untuk warga sekitar yang tidak mampu, artinya yang tidak mampu untuk menyekolahkan putra-putrinya ke SD Negeri. Jadi, para siswa tidak dibebani biaya apapun, termasuk uang gedung. Malah disediakan tas, sepatu, alat tulis bagi siswa yang betul-betul sangat tidak mampu.

Hasil temuan ini sejalan dengan teori yang disampaikan oleh Winardi dalam bukunya yang berjudul Aspek-aspek Bauran Pemasaran (Marketing Mix). Di buku tersebut dia menyampaikan bahwa dalam hal mempertimbangkan penetapan harga, para pemasar senantiasa harus mulai dengan mempertimbangkan sasaran-sasaran. Sasaran-sasaran penetapan harga (pricing

2 Fandy Tjiptono, Pemasaran Jasa Edisi Terbaru, (Yogyakarta: Andi Publisher, 2019), 383.

2 Rambat Lupiyoadi, Pemasaran Jasa, (Tangerăng: Penerbit Universitas Terbuka, 2017), 420. 
objectives) merupakan tujuan-tujuan secara menyeluruh yang menguraikan peranan harga dalam rencana-rencana jangka panjang suatu organisasi. ${ }^{2}$

Berdasarkan hasil temuan dan teori yang peneliti sajikan sangatlah jelas jika price dalam lembaga ini menyesuaikan dengan kondisi ekonomi orang tua siswa dan memperkuat teori dalam marketing mix.

3. Place (Lokasi)

Place merupakan salah satu strategi pemasaran yang berkaitan dengan tempat dimana lembaga pendidikan berada untuk melakukan aktivitas kegiatannya. Alasan-alasan wali murid menyekolahkan putra-putrinya ke SD NQ yang berkaitan dengan tempat. Pertama, sebab di lingkungan SD NQ suasananya asri dan sejuk. Kedua, karena SD NQ bertempat di lingkungan pondok pesantren yang diharapkan aliran keberkahannya. Ketiga, sebab letak SD NQ jauh dari jalan raya dan sungai, sehingga terhindar dari kebisingan yang dapat mengganggu keberlangsungan proses belajar dan mengajar. Juga tidak membuat khawatir para orang tua sebab putra-putri mereka tidak akan bermain di jalan raya dan sungai sehingga keamanan siswa betul-betul terjamin.

Lokasi SD NQ yang jauh dari kebisingan ini menjadi daya pikat untuk menarik calon siswa, sebab lokasi sekolah yang terhindar dari kebisingan adalah lokasi sekolah yang ideal.

Hasil temuan ini memperkuat pernyataan Pupu Saeful Rahmat yang mengatakan bahwa lingkungan yang nyaman akan mempermudah siswa-siswi untuk berkonsentrasi terhadap pembelajaran. Sebaliknya lingkungan sekolah yang tidak kondusif akan mengakibatkan siswa merasa tidak nyaman sehingga proses pembelajaran tidak dapat berjalan secara maksimal. ${ }^{2}$

Abdul Rahmat menyatakan, place atau letak lokasi sekolah mempunyai peran yang sangat penting, karena lingkungan di mana

2 Winardi, Aspek-aspek Bauran Pemasaran (Marketing Mix), (Bandung: Mandar Maju, 2019), 379.

2 Pupu Saeful Rahmat, Strategi Belajar Menğajar, (Jakarta: Scopindo, 2019), 65 . 
jasa disampaikan merupakan bagian dari nilai dan manfaat jasa yang mempersepsikan cukup berperan sebagai bahan pertimbangan dalam menentukan pilihan. ${ }^{2}$

Berdasarkan hasil temuan dan teori yang peneliti sajikan sangatlah jelas jika place di SD NQ berhasil memikat wali murid dan memperkuat teori Pupu Saeful Rahmat dan Abdul Rahmat.

4. Promotion (Promosi)

Suatu produk betapapun bermanfaat akan tetapi jika tidak dikenal oleh konsumen, maka produk tersebut tidak akan diketahui kemanfaatannya dan mungkin tidak akan dibeli oleh konsumen. Oleh karena itu, perusahaan harus berusaha mempengaruhi para konsumen, untuk menciptakan permintaan atas produk itu, kemudian dipelihara dan dikembangkan. ${ }^{2}$

Dalam melaksanakan kegiatan promosi, selain menyebarkan brosur ke lembaga TK/RA, memasang spanduk dan baliho di tempat strategis, presentasi ke lembaga-lembaga sasaran, dan men-share pamflet lembaga ke media sosial, kepala sekolah juga melakukan promosi dengan berkunjung ke tokoh masyarakat. Kepada mereka, kepala sekolah menyampaikan gambaran umum SD NQ yang meliputi program unggulan, biaya gratis, ruang kelas bersih, lingkungan asri, fasilitas yang dimiliki dan sebagainya. Serta mengadakan perlombaan pada event-event tertentu yang pesertanya adalah siswa-siswi TK/RA se-Kecamatan Sukowono, dengan maksud untuk memperkenalkan SD NQ.

Dengan merebaknya lembaga pendidikan di sekitar Sukowono, terutama di tingkat sekolah dasar, menuntut kepala sekolah untuk terus berinovasi dalam pelaksanaan promosi lembaga. Kepala sekolah sebagai inovator dalam pelaksanaan pemasaran akan melakukan secara kreatif, maksudnya akan mencari gagasan dan model baru yang belum pernah dilakukan oleh kepala sekolah yang lain atau sebelumnya.

2 Abdul Rahmat, Manajemen Humas Sekolah, (Yokyakarta: Media Akademik, 2016), 98.

2 Sofjan Assauri, Manajemen Pemasaran, $264 .{ }^{7}$ 

adalah:

Di antara inovasi yang telah diterapkan oleh kepala SD NQ

a. Pembagian zakat fitrah. Sebagai inovasi kepala SD NQ dalam kegiatan promosi adalah menjadikan SD sebagai baitul mal, kemudian pembagian zakat diserahkan langsung oleh siswa SD kepada mustahiq. Strategi inovasi pemasaran ini mengajarkan peduli kasih kepada sesama sejak kecil.

b. Khatmil Qur'an keliling, diadakan secara bergiliran oleh kepala sekolah dengan melibatkan siswa SD NQ. Kegiatan khatmil Qur'an ini diikuti oleh siswa kelas 4, 5 dan 6 yang bacaan alQur'annya baik dan lancar. Mereka mengaji di masjid dengan memakai loundspeaker. Masyarakat yang mendengar suara siswa yang sedang mengaji dengan fashahah dan tajwid yang benar, merasa kagum, lalu berminat untuk menyekolahkan putranya ke SD NQ.

Inovasi kepala sekolah dalam kegiatan promosi lembaga SD NQ ini selaras dengan pernyataan Direktur Jenderal Pendidikan Dasar dan Menengah Departemen Pendidikan Nasional dalam E. Mulyasa, mengatakan bahwa "Kepala sekolah sebagai inovator akan tercermin dari cara-cara lain melakukan pekerjaannya secara konstruktif, kreatif, delegatif, integratif, rasional dan objektif, pragmatis, keteladanan, disiplin serta adaptable dan fleksibel”. ${ }^{2}$

Inovasi yang kaitannya dengan kreativitas ditegaskan oleh Uhar Suharsaputra bahwa kreativitas menunjukkan pada pemunculan ide-ide baru yang memberi nilai tambah bagi seseorang atau organisasi memang perspektif kreativitas tidak tunggal, bahkan konseptualisasinya beragam. ${ }^{2}$

Hal ini juga diperkuat oleh Ratnawati, dkk., dengan menegaskan bahwa inovasi pemasaran adalah penerapan metode pemasaran yang baru atau peningkatan signifikan pengemasan atau desain produk, penempatan produk, promosi produk, atau harga.

2 E. Mulyasa, Manajemen $\mathcal{E}$ Kepemimpinan K'epala Sekolah, (Bandung: Remaja Rosdakarya, 2019), 118.

2 Uhar Suharsaputra, Kepemimpinan Inovasi Pendidikan, (Bandung: Refika Aditama, 2016), 274. 
Inovasi pemasaran bertujuan untuk meningkatkan penjualan, memenuhi kebutuhan konsumen, membuka pasar baru, dan menempatkan produk perusahaan dalam pasar. ${ }^{3}$

Berdasarkan hasil temuan dan teori yang peneliti sajikan di atas sangatlah jelas jika promotion SD NQ, baik yang dilakukan secara langsung ataupun tidak langsung, telah sejalan dengan pernyataan Direktur Jenderal Pendidikan Dasar dan Menengah Departemen Pendidikan Nasional, Uhar Suharsaputra dan Ratnawati.

\section{Simpulan}

Berdasarkan paparan hasil temuan penelitian, maka dapat dikemukakan dua simpulan untuk menjawab fokus penelitian yang telah dirumuskan di awal. Pertama, tugas kepala sekolah sebagai manajer dalam pemasaran di SD NQ, yaitu: 1) Perencanaan, meliputi: identifikasi pasar dan target pasar, b) Pengorganisasian dengan pembagian tugas sesuai jadwal yang disepakati, c) Pelaksanaan, yang terdiri: (1) Pemasaran secara langsung, yaitu penyebaran brosur, pemasangan baliho, presentasi ke lembaga dan mengunjungi tokoh, (2) Pemasaran tidak langsung, yaitu khatmil Qur'an keliling, drumband, pemuatan foto kegiatan, penyelenggaraan event lomba, program unggulan dan prestasi siswa, d). Pengawasan dengan evaluasi capaian, menunjukkan hasil yang dicapai sesuai keinginan.

Kedua, tugas kepala sekolah sebagai leader dalam pemasaran di SD NQ adalah dengan menerapkan strategi bauran pemasaran, ${ }_{4} \mathrm{P}$, yaitu: 1) Produk: program tahfidz juz 30 dan pengamalan pendidikan agama, 2) Harga: gratis tanpa biaya, 3) Tempat: sejuk, asri, terhindar dari keramaian dan menawarkan keberkahan, 4). Promosi: yang terdiri: (a) Promosi langsung, yaitu penyebaran brosur, pemasangan baliho, presentasi ke lembaga dan mengunjungi tokoh, (b) Promosi tidak langsung, yaitu khatmil Qur'an keliling, drumband, pemuatan foto kegiatan, penyeleng-garaan event lomba, pembagian zakat fitrah yang melibatkan siswa, program unggulan dan prestasi siswa.

3 Ratnawati, dkk., Inovasi Pemasaran Produk Unggul Berbasis Ekonomi Digital, (Jakarta: Balilatfo, 2019), 23. 


\section{Referensi}

Aaker A, David, Moorman, Christine, Strategic Market Management, Incorporated: John Wiley \& Sons, 2018.

Alma, Buchari, Manajemen Pemasaran E Pemasaran Jasa, Bandung: Alfabeta 2018.

Armstrong, Gary, and Philip Kotler, Principles of Marketing, Prentice Hall International: Pearson, 2019.

Assauri, Sofjan, Manajemen Pemasaran, Jakarta: Rajawali Pers, 2018.

Departemen Agama RI. Al-Qur'an dan Tafsirnya. Jilid IV. Jakarta: Lembaga Percetakan al-Qur'an Departemen Agama, 2009.

Fradito, Aditia. "Strategi Pemasaran Pendidikan dalam Meningkatkan Citra Sekolah.” Al-Idarah: Jurnal Kependidikan $\begin{array}{lllll}\text { Islam Volume } & 10 & \text { (2020): } & 12 . & \text { DOI: }\end{array}$ https://doi.org/10.24042/alidarah.v10i1.6203

Hasanah, Afidatun. "Pendidikan Sebagai Strategi Peningkatan Mutu di SD Alam Baturraden." Jurnal eL-Tarbawi 8 (2015): 161. DOI: http://dx.doi.org/10.20885/tarbawi.vol8.iss2.art4

Lisnawati, Aat. "Strategi Pemasaran Lembaga Pendidikan di Sekolah Dasar Dharma Mulia Dusun Banaran Getasan." Jurnal Ilmiah Ekonomi dan Bisnis Vol. 17 (2020): 198-205. DOI: https://doi.org/10.31849/jieb.v17i2.4422

Lupiyoadi, Rambat, Pemasaran Jasa, Tangerang: Penerbit Universitas Terbuka, 2017.

Mukmin, Baba. "Manajemen Pemasaran Jasa Sekolah Dasar Terpadu." Jurnal Isema: Islamic Education Manajemen 5 (2020): 97-112. $\quad$ DOI: http:// dx.doi.org/10.15575/isema.v5i1.6o76

Mulyasa, E., Manajemen E Kepemimpinan Kepala Sekolah, Bandung: Remaja Rosdakarya, 2019. 
Mulyasa, E., Menjadi Kepala Sekolah Profesional, Bandung: PT Remaja Rosdakarya, 2018.

Permendikbud Nomor 6 Tahun 2018, Tentang Penugasan Guru sebagai Kepala Sekolah.

Rahmat, Abdul, Manajemen Humas Sekolah, Yokyakarta: Media Akademik, 2016.

Ratnawati, dkk., Inovasi Pemasaran Produk Unggul Berbasis Ekonomi Digital, Jakarta: Balilatfo, 2019.

Saeful Rahmat, Pupu, Strategi Belajar Mengajar, Jakarta: Scopindo, 2019.

Sipetu, Ayu Sri Menda Br, Pengembangan Kreativitas Siswa, Bogor: Guepedia, 2019.

Suharsaputra, Uhar, Kepemimpinan Inovasi Pendidikan, Bandung: Refika Aditama, 2016.

Sunaeningsih, Cucun, Pengelolaan Pendidikan, Sumedang: UPI Sumedang Press, 2017.

Terry, George R., Prinsip-Prinsip Manajemen, terj. J. Smith. D.F.M., Jakarta: Bumi Aksara, 2018.

Tjiptono, Fandy, Pemasaran Jasa Edisi Terbaru, Yogyakarta: Andi Publisher, 2019.

Wijaya, David, Pemasaran Jasa Pendidikan, Jakarta: Bumi Aksara, 2016.

Winardi, Aspek-aspek Bauran Pemasaran (Marketing Mix), Bandung: Mandar Maju, 2019.

Wirtz, Jochen, Lovelock, Christopher, Services Marketing: People, Technology, Strategy, Eight Edition, USA: World Scientific, 2016. 